\title{
Blunted Affect
}

National Cancer Institute

\section{Source}

National Cancer Institute. Blunted Affect. NCI Thesaurus. Code C117195.

Restricted range of emotional expressiveness. 